\title{
Hepatic Focal Nodular Hyperplasia Developing after Childhood Cancers: Two-Center's Experience from Turkey
}

\author{
Deniz TUGCU ${ }^{1}$, Rejin KEBUDI ${ }^{2}$, Ferhan AKICI ${ }^{1}$, Ensar YEKELER ${ }^{3}$, Metin DEMIRKAYA ${ }^{4}$,

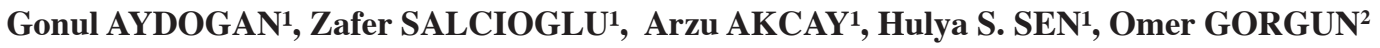

\author{
${ }^{1}$ Kanuni Sultan Süleyman Education and Research Hospital, Department of Pediatric Hematology and Oncology, Istanbul \\ 2 Istanbul University, Oncology Institute, Department of Pediatric Hematology and Oncology, Istanbul \\ ${ }^{3}$ Istanbul University, Istanbul Medical School, Division of Radiology, Istanbul \\ ${ }^{4}$ Uludag University, Uludag Medical School, Department of Pediatric Oncology, Bursa, TURKEY
}

\begin{abstract}
Even though Focal nodular hyperplasia $(\mathrm{FNH})$ is a rare lesion of the liver in children, it is reported at increased rates in treated pediatric cancer patients. The aim of this retrospective study is to describe the clinical and radiological characteristics and clinical course of patients diagnosed as FNH after primary malignancy in childhood. We retrospectively evaluated the diagnostic work-up, radiologic findings, clinical course and outcome of 8 patients, diagnosed as FNH after pediatric cancer treatment at the Department of Pediatric HematologyOncology of the Kanuni Sultan Suleyman Training and Research Hospital and Istanbul University, Oncology Institute, between 1993 and 2011. FNH lesions were diagnosed in 8 of 1600 solid tumors (0.5\%) after a median interval of $8(2-18)$ years, from the termination of the antineoplastic therapy for the primary cancer. Five patients had a history of neuroblastoma and two patients had rhabdomyosarcoma and one of them had primitive neuroectodermal tumor. FNH was incidentally found at USG or MRI performed during routine follow-up. Two children underwent surgical biopsies to rule out liver metastases. The lesions were stable for a median of 12 months (3-108 months) followup, no malign transformation was detected. FNH may be encountered as a radiological finding during follow-up in pediatric malignancies without hematopoetic stem cell transplantation and may be misdiagnosed as liver metastasis. FNH should be considered in the differential diagnosis of liver lesions encountered during follow up children with cancer. After the diagnosis of these benign lesions radiologically without biopsy, close imaging follow-up is recommended.
\end{abstract}

Keywords: Focal nodular hyperplasia, Pediatric cancer, Liver

\section{ÖZET}

\section{Çocukluk Çağı Kanserlerinden Sonra Gelişen Hepatik Fokal Noduler Hiperplazi: Türkiye'den İki Merkezin Deneyimi}

Fokal noduler hiperplazi (FNH), çocuklarda karaciğerin nadir görülen lezyonlarından olmasına rağmen, tedavi edilmiş çocuk kanser hastalarında artmış oranlarda bildirilmeye başlanmıştır. Bu retrospektif çalışmanın amacı, çocukluk çağı primer malinitesinden sonra, FNH tanısı alan hastaların klinik ve radyolojik karakteristiklerini ve klinik gidişini tanımlamaktır. Kanuni Sultan Eğitim ve Araştırma Hastanesi ve İstanbul Üniversitesi, Onkoloji Enstitüsü Pediatrik Hematoloji-Onkoloji Bilim Dalında, pediatrik kanser tedavisinden sonra, FNH tanısı alan 8 hastanın tanısal tetkikleri, radyolojik bulguları, klinik gidiş ve sonuçları retrospektif olarak değerlendirildi. FNH lezyonları, 1600 solid tümörlü hastanın 8'inde (0.5\%), primer kanser için kullanılan antineoplastik tedavinin sonlandırımasından 8 yıl (2-18) sonra tanımlandı. Beş hasta nöroblastom, 2 hasta rabdomyosarkom, 1 hasta da primitif neuroektodermal tumor nedeniyle tedavi edilmişti. FNH lezyonları, rastlantısal olarak, USG veya MRI ile rutin izlem sırasında saptandı. İki hastaya karaciğer metastazlarını ekarte etmek için, biyopsi uygulandı. Lezyonlar 12 aylık (3-108 ay) izlemleri sırasında stabil kaldı, maliniteye dönüşüm saptanmadı. FNH lezyonlarına, radyolojik olarak hematopoetik kök hücre nakli yapılmayan maliniteli çocuk hastalarda da rastlabilinir ve bu lezyonlar karaciğer metastazı olarak yanlış tanı alabilir. FNH, kanserli çocukların izleminde karşılaşılan karaciğer lezyonlarının ayıııcı tanısında düşünülmelidir. Bu iyi huylu lezyonların radyolojik olarak tanısından sonra, biyopsi yapılmadan yakın görüntüleme ile izlem önermekteyiz.

Anahter Kelimeler: Fokal nodüler hiperplazi, Pediatrik kanser, Karaciğer 


\section{INTRODUCTION}

Focal nodular hyperplasia (FNH) is a rare lesion of the liver in the pediatric population, but with the increase in life expectancy in pediatric cancer patients, FNH has been reported more frequently. ${ }^{1-7}$ It is considered to be a hyperplastic response to a preexisting vascular injury. ${ }^{89} \mathrm{FNH}$ is determined incidentally in USG, CT or MRI and maybe misinterpreted as liver metastasis in children with prior history of malignancy. FNH has been reported as case reports or case series after wide range of primary pediatric malignancies, including neuroblastoma, nephroblastoma, sarcoma, acute myeloid and lymphoid leukemia, Non-Hodgkin Lymphoma, germ cell tumor, medulloblastoma. FNH lesions are usually solitary, under $5 \mathrm{~cm}$, and asymptomatic in $80 \%$ to $95 \%$ of the patients.

\section{MATERIALS AND METHODS}

Clinical, laboratory, and radiological findings of 8 patients, who were treated for neuroblastoma (5 patients) and for rhabdomyosarcoma (RMS) (2 patients) and for primitive neuroectodermal tumour (PNET) (1 patient) at the Department of Pediatric HematologyOncology of the Kanuni Sultan Suleyman Training and Research Hospital and Istanbul University, Oncology Institute, between 1993 and 2009 and who were with FNH lesions in the liver during their observation between 2003 and 2011, were reviewed retrospectively.

Informed consent form for a retrospective study was obtained from all families. All of the patients informed form stored in patient's file. The neuroblastoma, patients had receieved multiagent chemotherapy consisting of vincristine (VCR), cisplatin (CDDP), etoposide (VP-16) and cyclophosphamide (CPA) according to the OPEC regimen, VCR, CDDP, VP-16, CPA, dacarbazine (DCB) and epirubicine (EPI) according to six in one regimen or VCR, iphosphamide (IFO), VP-16, carboplatinum (CBCDA) and EPI according to $\mathrm{BCH}$ (Birmingham Children's Hospital) neuroblastoma protocol.

Patients with RMS had been treated with VAC regimen, consisting of VCR, Actinomycin-D (Act-D), $\mathrm{CPA}$. The patient diagnosed with primitive neuroectodermal tumor (PNET) had recieved, multiagent chemotherapy consisting of IFO, VP-16, alternating with, adriamycine (ADR), VCR, CPA (IE/VAC) (Table 1).

$\left.\begin{array}{|lll|}\hline \text { Table 1. } & \text { Chemotherapy regimens for patients } \\ \hline \begin{array}{l}\text { Case } \\ \text { no }\end{array} & \begin{array}{l}\text { Chemotherapy } \\ \text { regimen }\end{array} & \text { Cumulative doses } \\ \hline 1 & \begin{array}{l}\text { OPEC } 2 \text { cycles, } \\ 6 \text { in one1 cycle }\end{array} & \text { VCR }\left(12 \mathrm{mg} / \mathrm{m}^{2}\right), \mathrm{CPA}\left(6000 \mathrm{mg} / \mathrm{m}^{2}\right), \mathrm{CDDP}\left(600 \mathrm{mg} / \mathrm{m}^{2}\right), \mathrm{VP}-16\left(700 \mathrm{mg} / \mathrm{m}^{2}\right), \\ & \text { DCB }\left(2000 \mathrm{mg} / \mathrm{m}^{2}\right), \text { EPI }\left(360 \mathrm{mg} / \mathrm{m}^{2}\right)\end{array}\right)$


International Journal of Hematology and Oncology

\begin{tabular}{|c|c|c|c|c|c|c|c|c|}
\hline Case no & 1 & 2 & 3 & 4 & 5 & 6 & 7 & 8 \\
\hline Primary diagnosis & Neuroblast & Neuroblast & Neuroblast & PNET & Neuroblast & Neuroblast & RMS & RMS \\
\hline Sex & $\mathrm{F}$ & M & M & M & M & M & $\mathrm{F}$ & M \\
\hline $\begin{array}{l}\text { Age at diagnosis } \\
\text { (months) }\end{array}$ & 24 & 24 & 12 & 12 & 7 & 19 & 132 & 60 \\
\hline $\begin{array}{l}\text { Years from primary } \\
\text { diagnosis to FNH }\end{array}$ & 4 & 10 & 8 & 9 & 8 & 2 & 18 & 5 \\
\hline $\begin{array}{l}\text { Following time for } \\
\text { FNH (months) }\end{array}$ & 30 & 7 & 108 & 12 & 19 & 12 & 3 & 3 \\
\hline $\begin{array}{l}\text { Localization of primary } \\
\text { tumor }\end{array}$ & R-Surrenal & L-surrenal & Mediastinum & Abdomen & L-surrenal & L-surrenal & $\begin{array}{l}\text { L-external } \\
\text { auditory canal }\end{array}$ & Pelvis \\
\hline Staging & $\|$ & III & III & $\|$ & III & III & $\|$ & $\|$ \\
\hline $\begin{array}{l}\text { Liver metastasis } \\
\text { at primer diagnosis }\end{array}$ & No & No & $\begin{array}{l}\text { No } \\
\|\end{array}$ & No & No & No & No & No \\
\hline $\begin{array}{l}\text { Liver dysfunction } \\
\text { during tumor therapy (Gr }\end{array}$ & $\begin{array}{l}\text { Yes (III) } \\
\text { arade) }\end{array}$ & No & No & No & No & Yes (III) & Yes (III) & Yes (II) \\
\hline VOD & None & None & None & None & None & None & None & None \\
\hline HSCT & None & None & None & None & None & None & None & None \\
\hline Radiation therapy & No & No & $\begin{array}{l}\text { RT } 15 \text { Gy } \\
\text { for tm bed }\end{array}$ & $\begin{array}{l}\text { No } \\
\text { No }\end{array}$ & $\begin{array}{l}\text { RT } 15 \text { Gy } \\
\text { for tm bed }\end{array}$ & $\begin{array}{l}\text { No } \\
\text { for tm bed }\end{array}$ & $\begin{array}{l}\text { RT } 42 \text { Gy } \\
\text { for tm bed }\end{array}$ & $\begin{array}{l}\text { RT } 42 \text { Gy } \\
\text { for tm bed }\end{array}$ \\
\hline Number of nodules & Multiple & Multiple & Solitary & Solitary & Multiple & Solitary & Multiple & Multiple \\
\hline Size of nodules (mm) & 35 & 18 & 30 & 10 & 12 & 9 & 48 & 56 \\
\hline Reason for USG & Follow-up & Follow-up & Follow-up & Follow-up & Follow-up & Follow-up & Follow-up & Follow-up \\
\hline Liver biopsy & Yes & No & Yes & No & No & No & No & No \\
\hline Biopsy finding & $\begin{array}{l}\text { Hepatocytes } \\
\text { displaying } \\
\text { regenerative and } \\
\text { degenerative } \\
\text { changes }\end{array}$ & - & $\begin{array}{l}\text { Minimal } \\
\text { parenchymal } \\
\text { degeneration, } \\
\text { mild } \\
\text { inflammatory } \\
\text { infiltration }\end{array}$ & - & - & - & - & - \\
\hline Treatment for FNH & No & No & No & No & No & No & No & No \\
\hline Complication & No & No & No & No & No & No & No & No \\
\hline $\begin{array}{l}\text { Final state of the } \\
\text { lesions (quantity) }\end{array}$ & Same & Same & Same & Same & Same & Same & Same & Same \\
\hline $\begin{array}{c}\text { Final state of the } \\
\text { lesions (size) }\end{array}$ & Same & Same & Same & Same & Same & Same & Same & Same \\
\hline
\end{tabular}

Liver dysfunction during tumor therapy was recorded according to National Cancer Institute Common Toxicity Criteria; NCI-CTC.

The diagnosis of focal nodular hyperplasia in the liver was made with imaging techniques. (ultrasonography, computerized tomography, magnetic resonance imaging) during follow-up and in two patients biopsy was performed.

All statistical analyses were performed using SPSS 16.0 software.

\section{RESULTS}

The diagnoses of the patients were stage II $(n=2)$, stage III $(n=3)$ neuroblastoma, rhabdomyosarcoma $(n=2)$ and nonmetastatic PNET $(n=1)$. Their ages at the time of primary tumour diagnosis were 7-132 months (32.85 \pm 44.19$)$, including 6 boys $(75 \%)$ and 2 girls $(25 \%)$.

Cumulative dose was $22.71 \pm 16.61 \mathrm{mg} / \mathrm{m}^{2}$ for $\operatorname{VCR}(\mathrm{n}=7)\left(12-60 \mathrm{mg} / \mathrm{m}^{2}\right), \quad 11233 \pm 7454 \mathrm{mg} / \mathrm{m}^{2}$ for CPA $(\mathrm{n}=6)\left(6000-26000 \mathrm{mg} / \mathrm{m}^{2}\right), 750 \pm 191.485$ $\mathrm{mg} / \mathrm{m}^{2}$ for CDDP $(\mathrm{n}=4) \quad\left(600-1000 \mathrm{mg} / \mathrm{m}^{2}\right)$, 


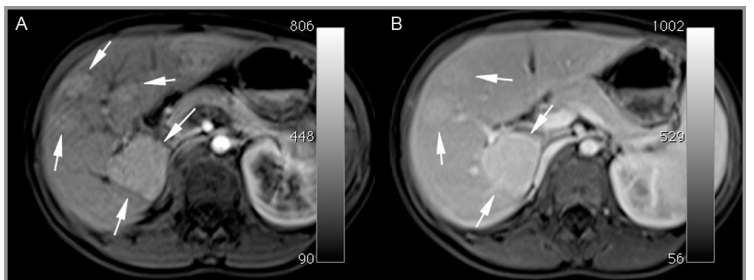

Figure $1 \mathbf{( a , b ) . ~ S i x ~ y e a r ~ o l d ~ g i r l ~ w i t h ~ a ~ h i s t o r y ~ o f ~ s t a g e ~ I I ~ r i g h t ~}$ surrenal neuroblastoma treated with chemotherapy. Liver MRI with $\mathrm{T} 1$ weighted images with contrast injection at the early (a) and late (b) arteriel phases, performed four years after the treatment, displays multiple hepatic nodules, from 10 to $35 \mathrm{~mm}$ large (Case 2). Characteristically, the lesions are isointense on T1-weighted images and slightly hyperintense on T2-weighted images. Early arteriel phase enhancement and late venous phase contrast fixation are also characteristics for $\mathrm{FNH}$.

$2666.667 \pm 1154.701 \mathrm{mg} / \mathrm{m}^{2}$ for DCB $(\mathrm{n}=3)(2000-$ $\left.4000 \mathrm{mg} / \mathrm{m}^{2}\right), \quad 390 \pm 103.923 \mathrm{mg} / \mathrm{m}^{2}$ for epi $(\mathrm{n}=4)$ $\left(360-440 \mathrm{mg} / \mathrm{m}^{2}\right), \quad 1583.333 \pm 1251.266 \mathrm{mg} / \mathrm{m} 2$ for VP-16 $(\mathrm{n}=6)\left(700-4000 \mathrm{mg} / \mathrm{m}^{2}\right), 17100 \pm 1272 \mathrm{mg} /$ $\mathrm{m}^{2}$ for IFO $(\mathrm{n}=2)\left(16200-18000 \mathrm{mg} / \mathrm{m}^{2}\right)$. After the five-six course of chemotherapy, radiotherapy was performed to three patients to tumor bed. None of the patients received radiotherapy to the liver and underwent hematopoetic stem cell transplantation (HSCT).

The median duration of time from initial diagnosis of cancer to initial diagnosis of FNH was 8 years (2-18 years). Primary localisation of the tumor was in the left surrenal $(n=3)$, right surrenal $(n=1)$, abdomen $(n=1)$, mediasten $(n=1)$, pelvis $(n=1)$ and left external auditory canal $(n=1)$. None of the patients had liver metastases at initial diagnosis or during followup. Grade III liver dysfunction during tumor therapy was detected in 3 patients and grade II in one patient according to National Cancer Institute Common Toxicity Criteria; NCI-CTC. Veno-occlusive disease wasn't observed in any patient during primary tumor treatment.

The lesions were identified during routine radiological observation in all the patients. None of the patients had any complain or any physical finding regarding liver or abdominal disease. No dysfunction was identified in liver function tests (Glutamic oksaloacetic transaminase, Glutamic pyruvate transaminase), alkaline phosphatase, gamma glutamyl transpeptidase, alpha-fetoprotein and neuron-specific enolase; after completion of tumor therapy and during the diagnosis of FNH.

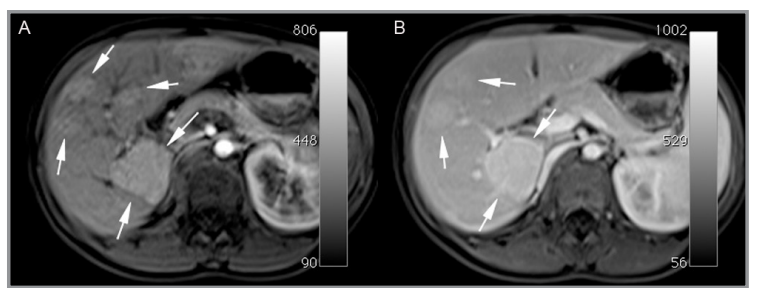

Figure 2 (a, b). Diffusion weighted image and ADC map exlude malignancy.

The lesions were identified with both USG and abdominal MR in all 8 patients. The dimensions of the lesions were between 9 and $56 \mathrm{~mm}$ and in the form of a solitary lesion in 3 patients and had a multifocal appearance in the other 5 patients. While two patients were diagnosed through radiological and histopathological examination, 6 patients were diagnosed with radiological findings only. Regenerative and degenerative changes in hepatocytes, minimal parenchyma degeneration, mild inflammatory infiltration were identified as biopsy findings. No significant change was observed in the lesion numbers and dimensions during the observations of the patients for 2-108 months $(27.14 \pm 36.76)$, consisting in abdominal US performed every 2-3 months (Table 2).

The lesions were variably hypo or isoechoic in ultrasonographic imaging. They had isointense or hypointense appearance in T1-weighted cross-sections and isointense or mildly hyperintense appearance in T2-weighted cross-sections (Figure 1, 2). Hyperintense central scar existed in T2-weighted cross-sections in two patient (patient 7, 8) (Table 3).

\section{DISCUSSION}

FNH comprises of hyperplastic benign tumour-like lesions. It is defined as thickened hepatic parenchyma surrounding the central fibrous scar. Even though their pathogenesis is not fully known, they are thought to be hyperplastic nodules that occur as a result of deterioration in the blood flow of the liver. Macroscopically, they contain abnormally dilated capsular blood vessels, and their frequency has been reported to increase with abdominal trauma resulting in intrahepatic vascular damage and after chemotherapy. Generally, the diagnosis is made incidentally during the follow-up of patients with tumor, so the real incidence is difficult to be determined. In our cases, all the diagnosis 


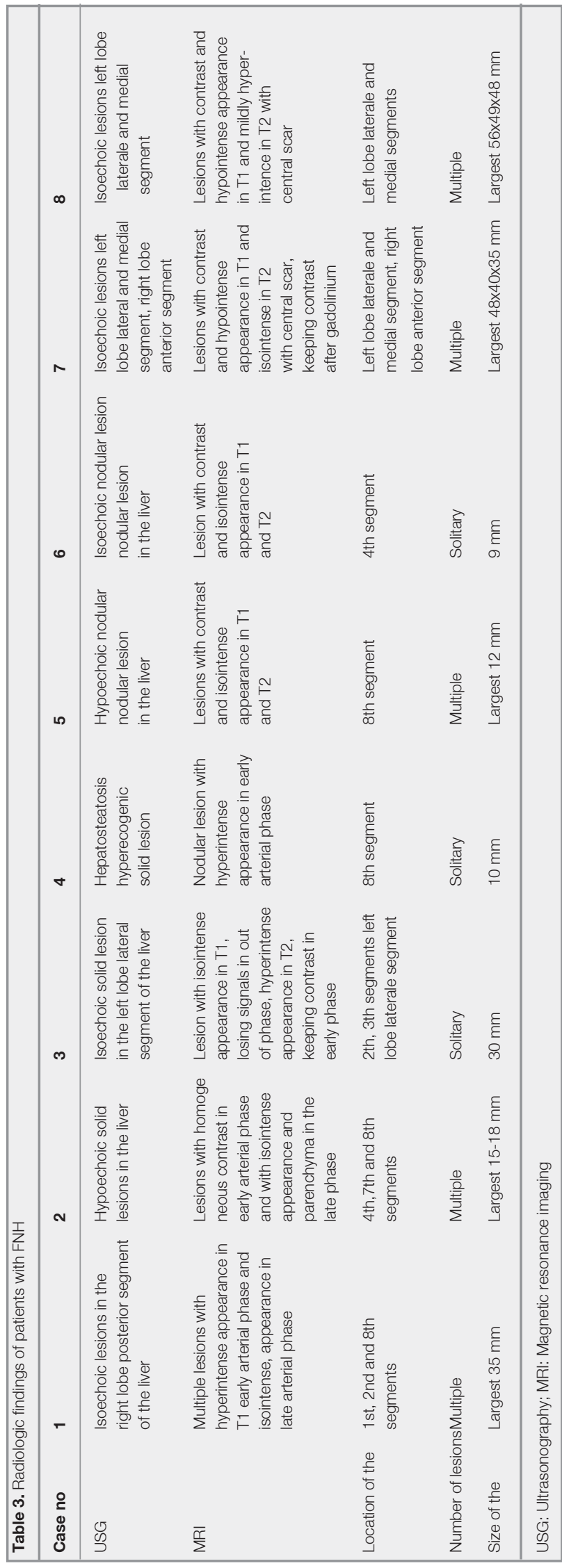

was made during routine follow-up without any complain, physical and laboratory finding.

It has been reported that high doses of alkylating agents used in neuroblastoma, radiotherapy to the liver, estrogen replacement treatments used following the discontinuation of chemotherapy, and bone marrow transplantation might constitute as risk factors for these lesions. ${ }^{1,10-14}$ In our patients, none of the patients had underwent bone marrow transplantation, none had had radiotherapy to the liver or abdomen, none of the girls had used oral contraceptives. However, high doses of alkylating agents such as CPA and IFO was used in all of the patients. There were more males $^{6}$ than female patients ${ }^{2}$ in our population.

FNH lesions are mostly solitary and under $5 \mathrm{~cm}$. The lesions may be slightly hypoechoic, isoechoic, or slightly hyperechoic by ultrasonography. As MRI findings, there is an iso- or hypointense appearance in T1-weighted cross-sections and a mildly hyperintense or isointense appearance in T2-weighted cross-sections and has a hyperintense central scar on T2-weighted images. There is contrast enhancement in the FNH lesions due to its arterial contents. An isointense appearance with the liver takes place in late stages. ${ }^{15,16,17}$ In our cases, 5 of seven patients had multiple FNH lesions, ranging size 9 from $48 \mathrm{~mm}$. On MRI, we detected central scar in two patient's lesions (patient 7,8), with the size of 48x40x35 mm and 56x49x48 mm.

It has been reported that gadolinium benzyloxy propionic tetraacetate ( Gd-BOPTA), which is the chelating agent of Gadobenate dimeglubine, may be used to characterize the FNH lesions to acquire detailed morphologic and functional information. ${ }^{18}$ Scintigraphic examination, on the other hand, is not recommended for diagnosis since it cannot distinguish FNH from hepatic adenoma.

Diagnosis should be made by eliminating other lesions and with radiological imaging. Monitoring with imaging techniques is sufficient to rule out liver metastasis and to monitor the evolution of the lesions. Biopsy is not recommended except for suspicious lesions. Surgery is suggested only in the case of complications. ${ }^{14}$

Even though no malignant changes have been reported in children, their association with hepatocellular carcinoma and other tumours have been defined in adults. ${ }^{19,20}$ Cases with intralesional bleeding and rupture have been reported. Since the lesions are 
vascular and capsule associated, the stretching of the capsule and the changes in the blood flow may cause pain. No changes were determined in the dimension and number of the lesions in our patients during their follow-up ranging between 2 months and 9 years.

In conclusion, FNH may develop in children receiving cancer treatment during follow-up. Ultrasound of the liver during follow-up to search for FNH is helpful. MRI should be done if suspicious lesions are found by ultrasound. Biopsy is not recommended if characteristics lesions are seen by radiological imaging. Multicentric studies with prospective follow-up for FNH lesions may lead to a more accurate incidence of these lesions following pediatric cancer.

\section{REFERENCES}

1. Bouyn $\mathrm{Cl}$, Leclere J, Raimondo G, et al. Hepatic focal nodular hyperplasia in children previously treated for a solid tumor. Incidence, risk factors, and outcome. Cancer 15: 97: 3107-3113, 2003.

2. Joyner BL Jr, Levin TL, Goyal RK, Newman B. Focal nodular hyperplasia of the liver: a sequela of tumor therapy. Pediatr Radiol 35: 1234-1239, 2005.

3. Junewick J, Mitchell D. Focal nodular hyperplasia in oncology patients. Pediatr Radiology 36: 464, 2006.

4. Marabelle A, Campagne D, Déchelotte P, et al. Focal nodular hyperplasia of the liver in patients previously treated for pediatric neoplastic diseases. J Pediatr Hematol Oncol 30: 546-549, 2008.

5. Citak EC, Karadeniz C, Oguz A, et al. Nodular regenerative hyperplasia and focal nodular hyperplasia of the liver mimicking hepatic metastasis in children with solid tumors and a review of literature. Pediatr Hematol Oncol 24: 281-289, 2007.

6. Anderson L, Gregg D, Margolis D, et al. Focal nodular hyperplasia in pediatric allogeneic hematopoietic cell transplant: case series. Bone Marrow Transplant 45: 1357-1359, 2010.

7. Sudour H, Mainard L, Baumann C,et al. Focal nodular hyperplasia of the liver following hematopoietic SCT. Bone Marrow Transplant 43: 127-32, 2009.

8. Wanless IR, Mawdsley C, Adams R. On the pathogenesis of focal nodular hyperplasia of the liver. Hepatology 5: 11942000, 1985.

9. Kumagai H, Masuda T, Oikawa H, et al. Focal nodular hyperplasia of the liver: direct evidence of circulatory disturbances. J Gastroenterol Hepatol 15: 1344-1347, 2000.

10. Scalori A, Tavani A, Gallus S, et al. Risk factors for focal nodular hyperplasia of the liver: an Italian case-control study. Am J Gastroenterol 97: 2371-2373, 2002.
11. Anderson L, Gregg D, Margolis D, et al. Focal nodular hyperplasia in pediatric allogeneic hematopoietic cell transplant: case series. Bone Marrow Transplant 45:1357-1359, 2010.

12. Sudour H, Mainard L, Baumann C, et al. Focal nodular hyperplasia of the liver following hematopoietic SCT. Bone Marrow Transplant 43:127-132, 2009.

13. Masetti R, Biagi C, Kleinschmidt K, et al. Focal nodular hyperplasia of the liver after intensive treatment for pediatric cancer: is hematopoietic stem cell transplantation a risk factor? Eur $\mathrm{J}$ Pediatr 170: 807-812, 2011.

14. Masetti R, Colecchia A, Rondelli R, et al. Benign hepatic nodular lesions after treatment for childhood cancer. J Pediatr Gastroenterol Nutr 56: 151-155, 2013.

15. Do RK, Shaylor SD, Shia J, et al. Variable MR imaging appearances of focal nodular hyperplasia in pediatric cancer patients. Pediatr Radiol 41: 335-340, 2011.

16. Marin D, Brancatelli G, Federle MP, et al. Focal nodular hyperplasia: typical and atypical MRI findings with emphasis on the use of contrast media. Clin Radiol 63: 577-85, 2008.

17. Hussain SM, Terkivatan T, Zondervan PE, et al. Focal nodular hyperplasia: findings at state-of-the-art MR imaging, US, CT, and pathologic analysis. Radiographics 24: 3-17, 2004.

18. Grazioli L, Morana G, Federle MP, et al. Focal nodular hyperplasia: morphologic and functional information from MR imaging with gadobenate dimeglumine. Radiology 221: 731-9, 2001.

19. Langrehr JM, Pfitzmann R, Hermann M, et al. Hepatocellular carcinoma in association with hepatic focal nodular hyperplasia. Acta Radiol 47: 340-344, 2006.

20. Zhang SH, Cong WM, WU MC. Focal nodular hyperplasia with concomitant hepatocellular carcinoma: a case report and clonal analysis. J Clin Pathol 57: 556-559, 2004.

\section{Correspondence}

Dr. Deniz TUĞCU

Kanuni Sultan Süleyman Eğitim ve Araştırma Hastanesi

Pediatrik Hematoloji ve Onkoloji Kliniği

Turgut Ozal Caddesi, No: 1

Halkalı, Küçükcekmece

ISTANBUL / TURKEY

Tel: (+90.212) 4041500

e-mail: deniztugcu@superonline.com 